Article

\title{
The Influence of Emotions, Motivation and Habits in the Academic Performance of Primary Education Students in French as a Foreign Language
}

\author{
Cristina Méndez-Aguado, José M. Aguilar-Parra *, Joaquín F. Álvarez®, Rubén Trigueros * and \\ José A. Fernández-Archilla \\ Department of Psychology, Hum-878 Research Team, Health Research Centre, University of Almería, \\ 04120 Almería, Spain; cristinamendezaguado@gmail.com (C.M.-A.); jalvarez@ual.es (J.F.Á.); \\ archijaf@hotmail.com (J.A.F.-A.) \\ * Correspondence: jmaguilar@ual.es (J.M.A.-P.); rtr088@ual.es (R.T.)
}

Received: 15 February 2020; Accepted: 19 March 2020; Published: 24 March 2020

\begin{abstract}
Schools have traditionally focused on the cognitive development of students without paying attention to how emotions modulate the students' psychological state and how this affects their academic performance. For that, the aim of this study is to determine the influence of emotions on the motivation of primary school students to learn French as a foreign language, and their influence on the adoption of adaptive habits and academic performance. For this purpose, the sample of participants consisted of 394 students who ranged in age from 10 to 13 years who answered three questionnaires on the study variables. Several statistical analyses were carried out that helped explain the causal relationships between the study variables and a predictive model hypothesized through structural equation modeling was created. The results revealed that positive emotion positively influenced academic motivation. At the same time, academic motivation was positively related to leisure habits related to French, and this was positively related to academic performance. In light of these results, the importance of attending to emotions in a foreign language class is highlighted, as well as the academic motivation of the students as it leads to adaptive behaviors and habits related to the learning of French.
\end{abstract}

Keywords: French as a foreign language; emotions; habits; academic motivation; academic performance

\section{Introduction}

Until now, existing studies in the field of education have focused mainly on students' cognitive processes, leaving emotional processes in the background [1]. This is, perhaps, because schools have traditionally focused on students' cognitive and behavioral development to assimilate a large amount of information [2]. Therefore, in recent years there has been an increase in school failure and dropout, which has highlighted the significant shortcomings of the Spanish education system that is sometimes unable to motivate and excite students towards their own learning [3]. In particular, learning foreign languages in Spain continues to be "a pending subject" in our educational system since, according to the latest report of the University of Cambridge Barometer (2017), the level of English among Spanish adolescents is far below that of countries such as Denmark, Germany, France or Italy, which is ranked 21st out of 27 in Europe [4]. Therefore, it is necessary to analyse the motivational and emotional processes inherent to the learning of French as a foreign language and its influence on academic habits and performance. 


\subsection{Emotions}

Emotions are organic reactions that alter an individual's state of mind by making him/her oscillate between euphoria and sadness and by conditioning the response to the situation he/she faces. They inform people about the situation they find themselves in so that they can adapt to and overcome it, predisposing them to action and influencing decision-making [5]. In this way, emotions are associated with the events experienced by individuals, making it easier to remember them and allowing them to remain in memory longer [6]. In the educational field, these events correspond to learning situations that take place in the classroom so that their memory, and therefore the acquisition of knowledge that is produced through them, is influenced by the emotions that the student experiences. In this sense, the experiences that students interpret as favorable in the classroom and that respond to their interests will be those that facilitate the development of positive emotions (e.g., fun, pride, confidence), in which case the memory of that situation or knowledge worked on is facilitated [7]. On the other hand, negative emotions (e.g., boredom, anxiety, frustration) make it difficult to remember and may even inhibit remember since they make it difficult to fix the information in the memory and recover it for the task at hand, so learning is reduced rather than stimulated $[8,9]$.

Existing studies in the field of education, including foreign language learning, have shown that students' learning is related to emotions. Thus, negative emotions decrease academic performance, while positive emotions increase it $[10,11]$. However, studies to date have been based on specific emotions, ignoring the possible presence of other emotions that may have a significant influence on motivation and/or academic performance [12]. However, one study by Lumby [13] only considered entertainment, studying its influence on the learning and performance level of secondary school students. At this same educational level, Yeager and others [14] analysed the existence of a negative correlation between boredom and math activities, while $\mathrm{Na}$ [15] found a negative correlation between anxiety and English learning. Likewise, Pulido and Herrera [16] carried out a study with primary, secondary and university students which showed that high levels of fear predict low academic performance, regardless of the school subject. In addition, Trigueros, Aguilar-Parra, Cangas, López-Liria and Álvarez [17] in their study with adolescents showed that shame is negatively related to motivation, which negatively influences learning and therefore academic performance.

\subsection{Motivation}

Motivation has been studied in recent years through the Self-Determination Theory (SDT), which distinguishes between two types of motivation. Autonomous motivation is related to the acquisition of new learning and involvement in a task $[18,19]$. On the other hand, controlled motivation is related to the lack of interest in the activity and the abandonment of it $[18,19]$. Therefore, it has been established that depending on the type of motivation developed by the students, students will try to stay in the proposed activity, developing an inherent learning towards the activity or not.

In this sense, autonomous motivation is related to an interest in language acquisition in order to know the language and be able to put it into practice in such a way that it benefits the learners' learning [20]. In the case of controlled motivation that has a marked instrumental character, the acquisition of the language does not have as its ultimate purpose its knowledge but responds to the achievement of an external objective [20]. In most cases, it is a non-optional learning imposed by external issues (e.g., parental pressure, qualifications) [17]. Thus, autonomous motivation responds to internal issues of the individual, while instrumental motivation is related to controlled motivation [21].

Studies in the academic field have shown that autonomous motivation is related to critical thinking, metacognition [18] and academic performance. Likewise, Moreno, González-Cutre, Martín-Albo and Cervelló [22] carried out a study with secondary school students in which the influence of autonomous motivation on academic performance in the area of physical education was demonstrated, and it was greater when faced with higher levels of motivation. These same conclusions were obtained by Kusurkar, Ten, Vos, Westers and Croiset [23], who carried out the research with a sample composed of students from a university medical centre. Likewise, Lemos and Veríssimo [24] carried out a study with 
primary school students in which the results showed that autonomous and controlled motivation can coexist, but that the former was systematically related to better performance during this educational stage. On the other hand, Carrió-Pastor and Mestre [25] focused their research on the acquisition of English as a foreign language at the university level. A greater predominance of instrumental motivation was detected. However, those students with integrative motivation were more successful in learning English.

Besides the postulates of the SDT, the studies of Dörnyei and Otto [26] stand out, where they underline the dynamic nature of motivation and how it varies over time. In this respect, a study carried out with secondary school students by Clément, Dörnyei and Noels [27] observed how motivation towards learning a foreign language is subordinated to two dimensions, the motivational influence (e.g., the social context) and the sequence of action, which refers to the original motivation, the one that sustains and the one that evaluates the process. However, this way of understanding motivation has a number of limitations since it analyses motivation from a continuous point of view, without considering the objective. Therefore, Dörnyei [20] incorporated the concept of ideal self-L2 (second language). This new element refers to the ideal L2 speaker that learners would like to become and is related to a renewed version of the concept of integrativeness by Gardner [28]. This ideal self can be a motivating force only if the learner's concept of planning and/or fantasizing about themselves includes becoming an L2 speaker. The L2 self that is aspired to has to do not with desires, but with the obligations and duties of the L2 learner and, therefore, it is related to controlled motivation which is related to abandonment of activity [29] and to the use of maladaptive cognitive strategies [30].

\subsection{Habits}

Emotions and motivation are not the only aspects to be taken into account in education, but the habits developed by the students also influence their academic performance. When we talk about habits at school, the most common thing is to associate them with study, that is, with the acquisition of new knowledge by students through repetitive actions that involve the organization of time and task [31]. However, there are other types of habits, understood as those activities that are carried out in free time and that, in addition to being of interest to the person, allow him/her to develop fully [32], offering the possibility of improving academic performance. Multiple studies have investigated this relationship in different subjects and school stages, demonstrating the existence of habits that benefit or limit students' academic performance. According to the first type, in the study carried out by Elche, Sánchez-García y Yubero [33], the relationship between reading habits and academic performance among the university population was analysed and the result was a positive relationship between the two, especially in terms of professional reading. On the other hand, and according to those negative habits, López [34] conducted his research with students belonging to the third cycle of primary education and obtained a negative correlation between the use of video games and academic performance. In the field of foreign languages, many habits have been identified which, when carried out in the classroom during the teaching-learning process, contribute to the improvement of students' academic performance. Studies such as the one carried out by Fonseca and Toscano [35] with primary education students have attributed special importance to the repetitive use of music. Use of music allows for the development of the four basic skills involved in learning a foreign language, known as oral and written expression and comprehension. At the same time, due to its emotional character, it awakens positive emotions in the students that promote the acquisition of new knowledge. Similarly, Martínez [36] carried out a literature review on the use of subtitles as an accompaniment to the viewing of films or series and established that it contributes to the improvement of the acquisition of the foreign language to be studied. It is the same with the realization of active readings that, as exposed in the review carried out by Hernández [37], allow the students to interact with the text, making learning much more significant. It should be noted that for the development of these types of habits, adequate motivation is necessary since it awakens the interest in the activity within the students, making it a leisure activity that is sustained over time. 


\subsection{Objective and Hypothesis}

Nowadays, more and more studies include among their objectives the identification of variables that influence academic performance. These include emotions, motivation and the development of leisure and free-time habits that act as a complement to the formal learning that takes place in the classroom. However, these are fragmented studies in which the number of emotions and habits contemplated is small, in addition to not establishing links between the three proposed variables: emotions, motivation, and leisure and free-time habits. Based on the above considerations, the following assumptions are made: (1) positive emotions (confidence, pride, fun and calmness) positively predict motivation towards learning French while negative emotions (shame, boredom, hopelessness and anxiety) negatively predict it; (2) motivation towards learning French positively predicts higher academic performance in the area of French; (3) motivation towards learning French positively predicts leisure and free-time habits related to the French language; (4) leisure and free-time habits related to French positively predict academic performance.

\section{Methods}

\subsection{Participants}

Two-hundred-and-one boys and 193 girls participated in this study. Their ages ranged from 10 to 13 years $(M=10.93 ; S D=0.75)$. The students studied at a bilingual education centre in the province of Almería.

The sample used was incidental and not probabilistic, depending on the accessibility we had to educational centers and students who attended classes.

\subsection{Instruments}

Emotions: The study employed the Emotion Questionnaire [38]. This questionnaire includes 34 items related to eight factors (five items for shame as well as for confidence, and four items for pride, fun, calm, boredom, hopelessness and anxiety). These items were evaluated through the students' response to a Likert scale on which values from 1 (strongly disagree) to 7 (strongly agree) were represented.

Academic Motivation: The students' motivation towards learning was measured through the academic motivation scale validated by Trigueros, Aguilar-Parra, Fernández-Campoy and Méndez-Aguado [39]. The scale was preceded by the heading "I participate in French class ... " and consists of 23 items grouped into six factors measuring intrinsic motivation, integrated regulation, identified regulation, introjected regulation, external regulation and de-motivation. Students responded using a Likert scale ranging from 1 (not true) to 7 (completely true).

To assess self-determined motivation, the self-determination index (SDI) was used [40], calculated on the basis of the following formula: $3 x$ intrinsic motivation, $2 x$ integrated regulation, $1 x$ identified regulation, $-1 x$ introjected regulation, $-2 x$ external regulation and $-3 x$ de-motivation. This index has been shown to be valid and reliable in several works [41-43], being used to obtain a value that allows for quantifying the level of self-determination.

Habits: This is a questionnaire created ad hoc for this study. The instrument takes into account the leisure and free-time habits developed by each student in their free time. The following were proposed: watching series, cartoons or films, listening to music, reading, talking to native/non-native speakers outside of school, playing games, going to an academy, going on an exchange or camp, and having French as a first language at school. Students had to answer yes (1) or no (0), with the maximum score being 10 points.

Academic performance: The final academic grades of the first and second quarter related to the subject of French as a foreign language of each student were used as a measure. The notes have been distributed as follows: 1 (fail), 2 (pass), 3 (good), 4 (fair) and 5 (excellent). 


\subsection{Procedure}

Before starting the study, several educational institutions were contacted and asked for their authorization. The parents or legal guardians of the study participants were then contacted as the study utilized minors, requiring them to give their signed informed consent. Both teachers and parents were informed of the objective of the study. It was explained to the students that they were participating in an investigation on the motivation towards French classes. Data collection took place before the start of classes. The questionnaires were completed anonymously and in accordance with all ethical procedures.

The administration of the scales to the participants was carried out under the supervision of an expert surveyor member of the research group, who explained and soled the doubts that arose when completing it. The estimated time to complete the questionnaires was about 25 minutes.

\subsection{Data Analysis}

First, the descriptive statistics, bivariate correlations and reliability analysis were calculated using the statistical program SPSS v25. Secondly, the predictive relationships between the study variables were analyzed through a structural equation model (SEM) using the statistical program AMOS v20.

We verified the multivariate normality of the data before performing the analysis. To do this we used bootstrap estimates along with the maximum likelihood estimation method because the Mardia's coefficient was high (355.19), showing that these estimates are robust to deviations from normality. In order to accept or reject the tested model, a set of several adjustment indices were used [44]: the chi-square coefficient divided by degrees of freedom $\left(\chi^{2} / \mathrm{df}\right)$, incremental rates (Incremental Fit Index, Comparative Fit Index and Tucker Lewis Index), root mean square error of approximation plus its $90 \%$ confidence interval and standardized root mean square residual. Since $\chi^{2}$ is very sensible to sample size [45], $\chi^{2} / \mathrm{df}$ was used with values below 5 [46]. Incremental rates show a good fit with values of 0.90 or higher [47], while values equal to or less than 0.08 for the error rated (root mean square error of approximation and standardized root mean square residual) are considered acceptable [48]. According to Marsh, Hau and Wen [49], the cut-off points described above should be considered with caution as they are quite restrictive when dealing with complex models.

\section{Results}

\subsection{Preliminary and Reliability Analysis}

Table 1 shows the descriptive statistics and correlations between the variables of the object of study. Pearson's correlations indicate that those emotions that have the same valence show a positive correlation, while those with a different valence have a negative correlation. Furthermore, positive emotions correlate positively with motivation (SDI), habits and academic performance. In contrast, negative emotions correlate negatively with motivation (SDI), habits and academic performance. Finally, habits are positively correlated with academic performance in both quarters. 
Table 1. Descriptive statistics and bivariate correlations.

\begin{tabular}{|c|c|c|c|c|c|c|c|c|c|c|c|c|c|}
\hline Factor & $\mathbf{M}$ & SD & 1 & 2 & 3 & 4 & 5 & 6 & 7 & 8 & 9 & 10 & 11 \\
\hline $\begin{array}{c}1 . \\
\text { Embarrassment }\end{array}$ & 2.12 & 0.96 & & $0.52^{* *}$ & $0.59 * *$ & $0.59^{* *}$ & $-0.41^{* *}$ & $-0.23^{* *}$ & $-0.24^{* *}$ & $-0.28 *$ & $-0.52 * *$ & $-0.27^{* *}$ & -0.29 ** \\
\hline 2. Boredom & 2.17 & 1.05 & & & $0.62 * *$ & $0.57^{* *}$ & -0.31 ** & -0.28 ** & -0.26 ** & $-0.33 * *$ & $-0.45^{* *}$ & $-0.25 *$ & $-0.32 * *$ \\
\hline 3. Hopelessness & 1.90 & 1.18 & & & & $0.50^{* *}$ & $-0.24 * *$ & $-0.29 * *$ & $-0.29 * *$ & $-0.37^{* *}$ & $-0.28 * *$ & $-0.22 * *$ & $-0.22 * *$ \\
\hline 4. Anxiety & 2.01 & 1.29 & & & & & -0.31 ** & -0.31 ** & $-0.30^{* *}$ & $-0.41 *$ & $-0.37^{* *}$ & $-0.32 * *$ & -0.13 * \\
\hline 5. Pride & 4.74 & 1.55 & & & & & & $0.40^{* *}$ & $0.47^{* *}$ & $0.49 *$ & 0.01 & 0.15 & $0.19 * *$ \\
\hline 6. Confidence & 4.68 & 1.27 & & & & & & & $0.48^{* *}$ & $0.62 * *$ & $0.21 *$ & $0.24^{* *}$ & $0.41^{* *}$ \\
\hline 7. Calmness & 4.79 & 1.44 & & & & & & & & $0.78^{* *}$ & $0.17 *$ & $0.25^{* *}$ & $0.35 * *$ \\
\hline 8. Enjoyment & 4.93 & 1.11 & & & & & & & & & $0.74^{* *}$ & $0.19^{* *}$ & $0.48^{* *}$ \\
\hline 9. SDI & 11.99 & 4.26 & & & & & & & & & & $0.56^{* *}$ & $0.64 * *$ \\
\hline $\begin{array}{l}\text { 10. Habits } \\
\text { French }\end{array}$ & 3.27 & 2.18 & & & & & & & & & & & $0.57^{* *}$ \\
\hline $\begin{array}{l}\text { 11. Academic } \\
\text { Performance }\end{array}$ & 8.11 & 1.75 & & & & & & & & & & & \\
\hline
\end{tabular}

$\mathrm{M}=$ Mean; $\mathrm{SD}=$ Standard Deviation; Note: ${ }^{* *} p<0.001 ;{ }^{*} p<0.01$.

Likewise, the reliability analysis through Cronbach's alpha showed a higher value of 0.70 for each of the study variables, specifically: 0.83 for the shame factor; 0.85 for pride; 0.81 for boredom; 0.86 for hopelessness; 0.88 for anxiety; 0.82 for confidence; 0.80 for calm and 0.80 for fun.

\subsection{Structural Equation Model}

To test the hypothesized predictive relations model, bootstrap analysis showed that the different estimates were not affected by the lack of normality and were therefore considered sufficiently robust [50]. The hypothesized predictive relationship model was tested (Figure 1). The analysis of the model obtained the following model fit indices: $\chi^{2}(621 \mathrm{~N}=294)=2128.68, p<0.001 ; \chi^{2} / g l=3.43$; $\mathrm{CFI}=0.95 ; \mathrm{TLI}=0.95 \mathrm{IFI}=0.95 ; \mathrm{RMSEA}=0.051(\mathrm{IC} 90 \%=0.048-0.059) ; \mathrm{SRMR}=0.039$.

The relations obtained between the different factors that make up the model are described below:

Hypothesis 1 (H1). Positive emotions (enjoyment, calmness, pride and confidence) positively predicted the motivation towards learning while negative emotions (anxiety, hopelessness, boredom and embarrassment) negatively predicted it (see Figure 1).

Hypothesis 2 (H2). Motivation towards learning positively predicted habits related to French $(\beta=0.39$, $p<0.01$.

Hypothesis 3 (H3). Learning motivation was positively related to academic performance in the first quarter $(\beta=0.48, p<0.001)$ and in the second quarter $(\beta=0.41, p<0.01)$.

Hypothesis 3 (H3). French-related habits positively predicted academic performance $(\beta=0.57, p<0.01)$.

Intra-class correlations of the observed variables for SDI, habits related to French, academic performance of the first quarter and academic performance of the second quarter were $0.41,0.17,0.24$ and 0.37 , respectively. This suggests that about $41 \%$ of the variation in SDI, $17 \%$ of the variation in habits related to French, $24 \%$ of the variation academic performance of the first quarter, and $37 \%$ of the variation academic performance of the second quarter existed between schools. In general, ratings were close to or above 0.20 , which is the remarkable value recommended by Hedges and Hedberg [51], suggesting the importance of students' emotions in their cognitive and behavioral processes related to learning French. 


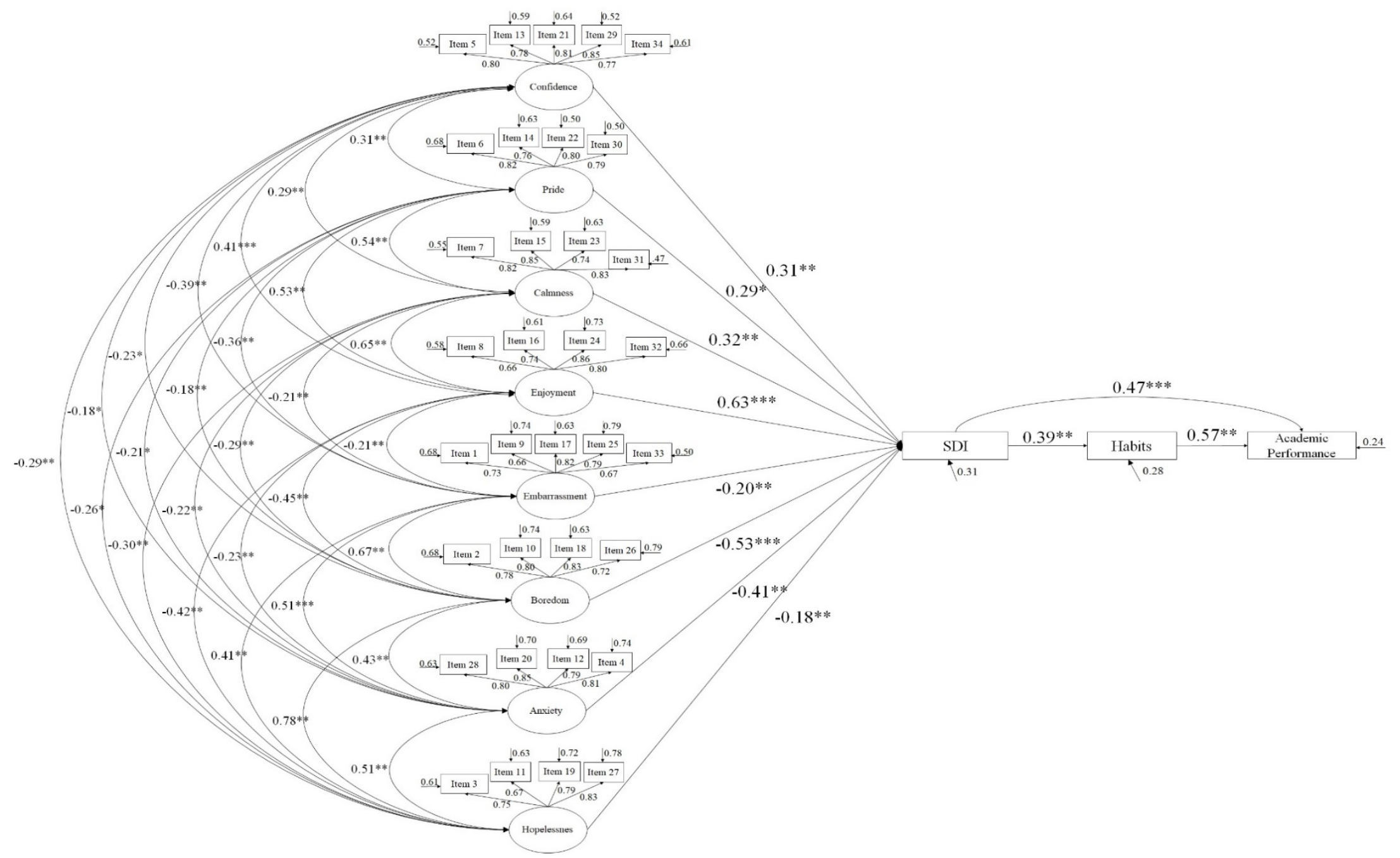

Figure 1. Hypothesized model of the educational context through a structural equation model where all the variables are related. All parameters are standardized and statistically significant. Note: ${ }^{* * *} p<0.001 ;{ }^{* *} p<0.01 ; * p<0.05$. 


\section{Discussion}

The aim of this research was to establish a relationship between emotions (positive and negative), motivation towards learning French, the development of leisure and free-time habits related to the French language, and the academic performance of primary school pupils of French as a foreign language. These variables have been extensively studied in numerous studies which have shown their importance and influence on the teaching-learning processes taking place in the classroom, regardless of the subject or school level. However, this research has studied these aspects in isolation [52]; therefore, the present study incorporates these variables in order to have a more holistic perspective on the variables that can influence academic performance.

The results obtained have shown how each of the positive emotions (enjoyment, calmness, pride and confidence) have been positively related to motivation for learning French, while each of the negative emotions (anxiety, hopelessness, boredom and embarrassment) have been negatively related to the motivation for learning French. These results are similar to several studies in the academic field. In this regard, a study by Wilson and Lewandowska-Tomaszczyk [53] with university philology students showed that those who were embarrassed to engage in conversation with the teacher and/or classmates in the language they were learning increased their anxiety and hopelessness, decreasing their interest and academic performance. In contrast, a study conducted by Méndez and Peña [54] with university students showed that fun, joy, and self-confidence increased students' interest in English classes. Thus, the results of the present study in relation to emotions, both positive and negative, regarding motivation towards learning French illustrate that teachers who try to promote knowledge of the concepts, foundations, skills and abilities related to learning French in the classroom using integrated and innovative methodologies will make the students feel more interested in French classes [55]. Therefore, it is logical to think that a positive emotional perception of the French classes will lead to a greater involvement of the students in these classes, which will lead to an adherence in other areas related to the French classes [56]. In this sense, if the French classes are tedious, monotonous and boring, the student is likely to create an animus towards the French classes. On the other hand, if the classes are enjoyable, fun and the teacher dedicates time to each student, the students are more likely to be motivated and interested in the French classes.

Moreover, the results have shown the positive relationship between motivation and leisure habits. It is evident that when faced with higher levels of motivation, behaviors are established that lead to a greater presence of habits that allow students to increase their performance in relation to French as a foreign language. In this sense, we have no evidence that previous studies have studied this relationship in the area of French; however, there are studies which have focused on parallel behaviors linked to motivation of the academic area, contributing to adopting stable adaptive habits. In this respect, a study carried out with high school students by McGeown, Duncan, Griffiths and Stothard [57] showed that in terms of reading habits, the presence of motivation towards it improves comprehension and reading speed. This happens because leisure habits are chosen by students; that is, they respond to their interests and therefore form intrinsic goals, which, as established by Garrote, Garrote and Jiménez [58], are closely linked to motivation. In this way, the more interest they show towards a goal, the more possibilities there are for them to develop more habits related to it.

Finally, the results of the study have shown how leisure habits related to the French have positively predicted academic performance. Thus, the more French leisure habits a student has, the higher his/her academic performance will be. These results are comparable to previous studies where they related specific leisure habits to academic performance. A study carried out by Corpas [59] with high school students showed that listening to music in English contributes to the development of reading comprehension, which favors students' academic performance. Similarly, a study by Santos-Díaz [60] showed that frequent reading improves vocabulary acquisition, which is a determining factor in greater understanding of the language and higher student performance during activities and exams. In this way, habits related to communicative exchange with French speakers and those behaviors linked to playful aspects such as games or the viewing of drawings contribute to improving academic 
performance in a conscious and unconscious way $[60,61]$. This relationship is established because the development of leisure habits allows for the acquisition of knowledge directly and indirectly, in addition to being a complement to classroom learning. In this sense and in line with this research, it may be concluded that if each of these habits improves academic performance in a foreign language, the more habits there are, the greater the improvement.

\section{Limitations}

Despite the existing results, with regard to the model presented it is necessary to underline that it is a relational study and therefore the explanations between the variables can be interpreted differently depending on the person's point of view. Therefore, we have tried to present possibilities in order to explain the relationships between the variables of the study. In addition, future research should study how teachers, friends and family can influence the development of students' emotional state and motivation in relation to French and its influence on the level of linguistic competence. Furthermore, future work should look at the differences between boys and girls in relation to French leisure habits and academic performance.

\section{Conclusions}

According to the results obtained, this research has highlighted the importance of the emotions experienced by students during the process of learning French as a foreign language, as well as the motivation, leisure and free-time habits they develop. The aim is to make teachers aware of the link between the teaching-learning process and emotions since the affective aspect is intrinsic to them and influences students' performance. At the same time, one cannot forget the role of motivation in the acquisition of leisure and free-time habits and the importance of their development for the improvement of the learning of French as a foreign language. Knowing which habit is more convenient and how to carry each out, they act as an aid or complement to the learning that takes place in the classrooms.

Author Contributions: Conceptualization, C.M.-A. and R.T.; Data curation, C.M.-A. and J.M.A.-P.; Formal analysis, J.M.A.-P. and J.A.F.-A.; Investigation, J.F.Á.; Methodology, J.F.Á. and R.T.; Project administration, J.M.A.-P.; Resources, J.F.Á., J.M.A.-P.; Software, J.A.F.-A.; Visualization, R.T.; Writing—original draft, C.M.-A. and R.T.; Writing - review \& editing, J.M.A.-P. All authors have read and agreed to the published version of the manuscript.

Funding: This research received no external funding.

Conflicts of Interest: The authors declare no conflict of interest.

\section{References}

1. Frenzel, A.C.; Becker-Kurz, B.; Pekrun, R.; Goetz, T.; Lüdtke, O. Emotion transmission in the classroom revisited: A reciprocal effects model of teacher and student enjoyment. J. Educ. Psychol. 2018, 110, 628-639. [CrossRef]

2. Barajas, M.; Gannaway, G.J. Implementing E-learning in the traditional higher education institutions. High. Educ. Eur. 2007, 32, 111-119. [CrossRef]

3. Oriol-Granado, X.; Mendoza-Lira, M.; Covarrubias-Apablaza, C.G.; Molina-López, V.M. Emociones positivas, apoyo a la autonomía y rendimiento de estudiantes universitarios: El papel mediador del compromiso académico y la autoeficacia. Rev. Psicodidáctica 2017, 22, 45-53. [CrossRef]

4. Education First. Índice FL de Nivel de Inglés; Education First: Lucerne, Switzerland, 2018.

5. Bisquerra, R. Educación Emocional y Competencias Básicas para la vida. Rev. Investig. Educ. 2003, 21, 7-43.

6. Ruetti, E.; Ortega, I.S.; Martín, J. Emociones y cognición: Factores moduladores del aprendizaje y la memoria en niños y adolescentes. In Repensando la psicología educativa en la sociedad del conocimiento; Universidad nacional de educación Enrique Guzmán y Valle. Escuela de posgrado: Lima, Perú, 2014; pp. 73-86.

7. Pell, M.D.; Monetta, L.; Paulmann, S.; Kotz, S.A. Recognizing emotions in a foreign language. J. Nonverbal Behav. 2009, 2, 107-120. [CrossRef] 
8. Di Gesù, F.; Seminara, A. Neurodidáctica y la implicación de emociones en el aprendizaje. Lynx Panorámica Estud. Lingüísticos 2012, 11, 5-39.

9. McConnell, M. Emociones en educación: Cómo las emociones, cognición y motivación influyen en el aprendizaje y logro de los estudiantes. Rev. Mex. Bachill. A Distancia 2019, 11, 109-129. [CrossRef]

10. García, C.A.; Durán, N.C. Revisiting the concept of self-efficacy as a language learning enhancer. Gist Educ. Learn. Res. J. 2017, 15, 68-95.

11. García, M.D.; Miller, R. Disfemia y ansiedad en el aprendizaje de inglés como lengua extranjera. Rev. Española Discapac. 2019, 7, 87-109. [CrossRef]

12. Trigueros-Ramos, R.; Gómez, N.N.; Aguilar-Parra, J.M.; León-Estrada, I. Influencia del docente de Educación Física sobre la confianza, diversión, la motivación y la intención de ser físicamente activo en la adolescencia. Cuadernos de Psicología del Deporte. 2019, 1, 222-232. [CrossRef]

13. Lumby, J. Enjoyment and learning: Policy and secondary school learners' experience in England. Br. Educ. Res. J. 2011, 37, 247-264. [CrossRef]

14. Yeager, D.S.; Henderson, M.D.; Paunesku, D.; Walton, G.M.; D’Mello, S.; Spitzer, B.J.; Duckworth, A.L. Boring but important: A self-transcendent purpose for learning fosters academic self-regulation. J. Personal. Soc. Psychol. 2014, 107, 559. [CrossRef]

15. Na, Z. A study of high school students' English learning anxiety. Asian EFL J. 2007, 9, $22-34$.

16. Pulido, F.; Herrera, F. La influencia de las emociones sobre el rendimiento académico. Cienc. Psicológicas 2017, 11, 29-39. [CrossRef]

17. Trigueros, R.; Aguilar-Parra, J.M.; Cangas, A.; López-Liria, R.; Álvarez, J.F. Influence of physical education teachers on motivation, embarrassment and the intention of being physically active during adolescence. Int. J. Environ. Res. Public Health 2019, 16, 2295. [CrossRef] [PubMed]

18. Trigueros, R.; Navarro, N. La influencia del docente sobre la motivación, las estrategias de aprendizaje, pensamiento crítico y rendimiento académico de los estudiantes de secundaria en el área de Educación Física. Psichol. Soc. Educ. 2019, 11, 137-150. [CrossRef]

19. Ryan, R.M.; Deci, E.L. Self-Determination Theory: Basic Psychological Needs in Motivation, Development, and Wellness; Guilford Publications: New York, NY, USA, 2017.

20. Beltrán, L. Influencia cultural en la motivación para el aprendizaje del inglés como lengua extranjera. Rev. Int. Investig. Educ. Y Pedagog. 2015, 8, 341-371. [CrossRef]

21. Dörnyei, Z. The L2 motivational self-system. In Motivation, Language Identity and the L2 Self; Dörnyei, Z., Ushioda, E., Eds.; Multilingual Matters: Bristol, UK, 2009; pp. 9-42.

22. Zenotz, V. Motivación en el aprendizaje de lenguas: Estado de la cuestión. Huarte de San Juan. Filol. Y Didáctica Leng. 2012, 12, 75-81.

23. Moreno, J.A.; González-Cutre, D.; Martín-Albo, J.; Cervelló, E. Motivación y rendimiento en la educación física: Una prueba experimental. Rev. Educ. Física Renov. Teoría Y Práctica 2018, 36, 39-46.

24. Kusurkar, R.A.; Ten, T.J.; Vos, C.M.; Westers, P.; Croiset, G. How motivation affects academic performance: A structural equation modeling analysis. Adv. Health Sci. Educ. 2013, 18, 57-69. [CrossRef]

25. Lemos, M.S.; Veríssimo, L. The relationship between intrinsic motivation, extrinsic motivation, and achievement, along elementary school. In Proceedings of the IV International Conference on Education and Education Psychology, Antalya, Turkey, 2-5 October 2013.

26. Carrió-Pastor, M.L.; Mestre, E.M. Motivation in second language acquisition. In Proceedings of the V World Conference on Education Sciences, Rome, Italy, 5-8 February 2013; Faculty of Economics: Rome, Italy, 2013.

27. Dörnyei, Z.; Ottó, I. Motivation in Action: A Process Model of L2 Motivation; Working Papers in Applied Linguistics; Thames Valley University: London, UK, 1998; pp. 43-69. Available online: http://eprints. nottingham.ac.uk/39/2/Motivation_in_action.pdf (accessed on 19 January 2020).

28. Clément, R.; Dörnyei, Z.; Noels, K.A. Motivation, self-confidence, and group cohesion in the foreign language classroom. Lang. Learn. 1994, 3, 417-448. [CrossRef]

29. Gardner, R.C. Motivation and Second Language Acquisition: The Socio-Educational Model; Peter Lang: New York, NY, USA, 2010.

30. Dörnyei, Z. Motivational Strategies in the Language Classroom; Cambridge University Press: Cambridge, UK, 2001. 
31. Trigueros, R.; Aguilar Parra, J.M.; Lopez-Liria, R.; Cangas, A.J.; González, J.J.; Álvarez, J.F. The role of the teacher in the students' motivation and emotions. The impact on metacognition strategies and academic performance in maths and English classes. Front. Psychol. 2019, 10, 2794. [CrossRef] [PubMed]

32. Pérez, V.M.O.; Barberis, L.T. Análisis de los hábitos de estudio en una muestra de alumnos universitarios. Rev. Iberoam. Educ. 2005, 36, 1-9.

33. Sarrate, M.A. Ocio y tiempo libre en los centros educativos. Bordón 2008, 60, 51-61.

34. Elche, M.; Sánchez-García, S.; Yubero, S. Lectura, ocio y rendimiento académico en estudiantes universitarios del área socioeducativa. Educación 2019, 22, 215-237. [CrossRef]

35. López, F. Relación entre el hábito de consumo de videojuegos y el rendimiento académico. Diferencias de género y edad en tercer ciclo de educación primaria. Int. J. Dev. Educ. 2011, 1, 603-611.

36. Fonseca, C.; Toscano, C.M. La música como herramienta facilitadora del aprendizaje del inglés como lengua extranjera. Teoría Educ. Rev. Interuniv. 2012, 24, 197-213.

37. Martínez, A. Passive learning. The impact of TV shows on students' learning behaviours and performance. In Aprendizajes Plurilingües y Literarios. Nuevos Enfoques; Publicaciones de la Universidad de Alicante: Alicante, España, 2016; pp. 149-154.

38. Hernández, M.J. Del pretexto al texto. La lectura en la enseñanza/aprendizaje de idiomas y su tratamiento en español como lengua extranjera. Marco ELE. Rev. De Didáctica Español Leng. Extranj. 2007, 5, 1-11.

39. Trigueros, R.; Aguilar-Parra, J.M.; Cangas, A.J.; Álvarez, J.F. Validation of the Scale of Emotional States in the Physical Education Context. Sustainability 2019, 11, 5006. [CrossRef]

40. Trigueros, R.; Aguilar-Parra, J.M.; Fernández-Campoy, J.M.; Méndez-Aguado, C. Adaptación y validación de la escala de motivación académica en secundaria con la incorporación de la regulación integrada y la desmotivación. In Innovación Educativa en la Sociedad Digital; Dykinson: Madrid, Spain, 2020.

41. Vallerand, R.J. Intrinsic and extrinsic motivation in sport and physical activity. Handb. Sport Psychol. 2007, 3, 59-83.

42. Ünlü, A. Adjusting potentially confounded scoring protocols for motivation aggregation in organismic integration theory: An exemplification with the relative autonomy or self-determination index. Front. Psychol. 2016, 7, 272. [CrossRef] [PubMed]

43. Cecchini, J.A.; Fernández-Río, J.; Méndez-Giménez, A.; Carriedo, A.; Arruza, J.A. A self-determination approach to the understanding of the impact of physical activity on depressive symptoms. Stress Health 2017, 5, 600-607. [CrossRef] [PubMed]

44. Ulstad, S.O.; Halvari, H.; Deci, E.L. The role of students' and teachers' ratings of autonomous motivation in a self-determination theory model predicting participation in physical education. Scand. J. Educ. Res. 2019, 7, 1086-1101. [CrossRef]

45. Hu, L.; Bentler, P.M. Cutoff criteria for fit indexes in covariance structure analysis: Conventional criteria versus new alternatives. Struct. Equ. Model. 1999, 6, 1-55. [CrossRef]

46. Jöreskog, K.G.; Sörbom, D. LISREL 8: Structural Equation Modeling with the SIMPLIS Command Language; Scientific Software: Chicago, IL, USA, 1993.

47. Bentler, P.M. EQS Structural Equations Program Manual; BMDP Statistical Software: Los Angeles, CA, USA, 1989.

48. Schumacker, R.; Lomax, R.G. A Beginner's Guide to Structural Equation Modelling; Lawrence Erlbaum Associates Inc.: Mahwah, NJ, USA, 1996.

49. Marsh, H.W.; Hau, K.T.; Wen, Z. In search of golden rules: Comment on hypothesis-testing approaches to setting cutoff values for fit indexes and dangers in overgeneralizing Hu and Bentler's (1999) findings. Struct. Equ. Model. 2004, 11, 320-341. [CrossRef]

50. Browne, M.W.; Cudeck, R. Alternative ways of assessing model fit. Sage Focus Ed. 1993, 154, 136. [CrossRef]

51. Byrne, B.M. Structural equation modeling with AMOS, EQS, and LISREL: Comparative approaches to testing for the factorial validity of a measuring instrument. Int. J. Test. 2001, 1, 55-86. [CrossRef]

52. Hedges, L.V.; Hedberg, E.C. Intraclass correlation values for planning group-randomized trials in education. Educ. Eval. Policy Anal. 2007, 1, 60-87. [CrossRef]

53. Trigueros, R.; Aguilar-Parra, J.M.; López-Liria, R.; Rocamora, P. The dark side of the self-determination theory and its influence on the emotional and cognitive processes of students in physical education. Int. J. Environ. Res. Public Health 2019, 22, 4444. [CrossRef] 
54. Wilson, P.A.; Lewandowska-Tomaszczyk, B. Shame and anxiety with foreign language learners. In The Bright Side of Shame; Springer: Cham, Switzerland, 2019; pp. 315-332.

55. Méndez, M.G.; Peña, A. Emotions as learning enhancers of foreign language learning motivation. Profile Issues Teach. Prof. Dev. 2013, 1, 109-124.

56. Pym, A.; Ayvazyan, N. Linguistics, translation and interpreting in foreign-language teaching contexts. In The Routledge Handbook of Translation Studies and Linguistics; Routledge: Abindon, UK, 2017; pp. $393-407$.

57. Li, C.; Jiang, G.; Dewaele, J.M. Understanding Chinese high school students' foreign language enjoyment: Validation of the Chinese version of the foreign language enjoyment scale. System 2018, 76, 183-196. [CrossRef]

58. McGeown, S.P.; Duncan, L.G.; Griffiths, Y.M.; Stothard, S.E. Exploring the relationship between adolescent's reading skills, reading motivation and reading habits. Read. Writ. 2015, 28, 545-569. [CrossRef]

59. Garrote, D.; Garrote, C.; Jiménez, S. Factores influyentes en motivación y estrategias de aprendizaje en los alumnos de grado. REICE. Rev. Iberoam. Sobre Calid. Efic. Y Cambio Educ. 2016, 14, 31-44.

60. Corpas, M.D. La educación informal en el aprendizaje del inglés como lengua extranjera. Tejuelo 2016, 24, 68-91.

61. Aguayo, M.; Bravo, M.; Nocetti, A.; Concha, L.; Aburto, R. Perspectiva estudiantil del modelo pedagógico flipped classroom o aula invertida en el aprendizaje del inglés como lengua extranjera. Rev. Educ. 2019, 43. [CrossRef]

(C) 2020 by the authors. Licensee MDPI, Basel, Switzerland. This article is an open access article distributed under the terms and conditions of the Creative Commons Attribution (CC BY) license (http://creativecommons.org/licenses/by/4.0/). 